\title{
Equipment
}

\section{The accuracy and variability of bolus injections with different sized syringes}

The accuracy of bolus injections using different sized syringes was studied. A I ml bolus was delivered from a $1 \mathrm{ml}, 5 \mathrm{ml}, 10 \mathrm{ml}$, and a $20 \mathrm{ml}$ syringe $(n=205)$. The $1 \mathrm{ml}$ syringe was the most accurate $(P<0.001)$ and the bolus delivered was the least variable $(P<0.001)$. Variability increased as syringe size increased. A $3 \mathrm{ml}$ bolus was delivered from a $3 \mathrm{ml}, 5 \mathrm{ml}, 10 \mathrm{ml}$, and $a 20 \mathrm{ml}$ syringe $(n=164)$. The $5 \mathrm{ml}$ syringe was the most accurate $(P<0.05)$ and the $3 \mathrm{ml}$ and $5 \mathrm{ml}$ syringes delivered $a$ bolus with the least variability $(P<0.001)$. A $5 \mathrm{ml}$ bolus was delivered from a $5 \mathrm{ml}, 10 \mathrm{ml}$, and a $20 \mathrm{ml}$ syringe ( $n=123)$; in this case there was no significant difference in the accuracy or variability of bolus among the three syringes. We conclude that for accuracy of small volume boluses $(<5 \mathrm{ml})$, small-sized syringes should be used.

La précision des injections en bolus a été étudiée en utilisant des seringues de différentes grosseurs. Un bolus de $1 \mathrm{ml}$ a été injecté à l'aide de seringues de $1,5,10$ et $20 \mathrm{ml}(n=205)$. La seringue de $1 \mathrm{ml}$ était la plus précise $(P<0,001)$, et présentait une variabilité moindre du bolus $(P<0,001)$. La variabilité augmentait avec les seringues plus grosses. Un bolus de $3 \mathrm{ml} \mathrm{a}$ été injecté à l'aide de seringues de 3,5,10 et $20 \mathrm{ml}(\mathrm{n}=164)$. La seringue de $5 \mathrm{ml}$ était la plus précise $(P<0,05)$ et les seringues de 3 et $5 \mathrm{ml}$ présentaient une variabilité moindre $(P<$ $0,001)$. Un bolus de $5 \mathrm{ml}$ a été injecté à l'aide de seringues de 5 , 10 et $20 \mathrm{ml}(n=123)$; dans ce cas, il n'y avait aucune différence significative entre les trois seringues en ce qui a trait à la

\section{Key words}

EQUIPMENT: syringes.

From the Department of Anaesthesia, British Columbia's Children's Hospital, and the University of British Columbia.

Address correspondence to: Dr. David J. Steward, Director of Anesthesiology, Childrens Hospital of Los Angeles, 4560

Sunset Boulevard, Los Angeles, Ca. 90027, USA.

Accepted for publication 23rd September, 1991.
Shafik U. Thobani MD, David J. Steward FRCPC

précision ou à la variabilité du bolus. Nous en concluons que pour obtenir une bonne précision des bolus de petit volume $1<5$ $m l)$, des seringues de petite grosseur devraient être utilisées.

In order to deliver small volumes of drug doses accurately it has been suggested that the anaesthetist should employ the smallest size syringe that will accommodate the desired amount. However, the accuracy with which small volumes can be delivered with various sized syringes has never, to our knowledge, been objectively studied. We have therefore conducted a study to define the confidence limits for measurement of standard volumes using various sized syringes. Accuracy we defined as the ability to deliver the exact desired volume, variability we assessed from the ability to repeatedly deliver exactly equal volumes.

\section{Methods}

The studies were designed to determine the accuracy and variability of delivery of:

(a) A $1 \mathrm{ml}$ bolus from each of a $1 \mathrm{ml}, 3 \mathrm{ml}, 5 \mathrm{ml}, 10 \mathrm{ml}$, and $20 \mathrm{ml}$ syringe.

(b) A $3 \mathrm{ml}$ bolus from each of a $3 \mathrm{ml}, 5 \mathrm{ml}, 10 \mathrm{ml}$, and 20 ml syringe.

(c) A $5 \mathrm{ml}$ bolus from each of a $5 \mathrm{ml}, 10 \mathrm{ml}$, and $20 \mathrm{ml}$ syringe.

Each syringe to be tested was filled to capacity with sterile water which was assumed to weigh one $\mathrm{g} \cdot \mathrm{ml}^{-1}$ at room temperature. Care was taken to extrude all air bubbles from the syringe. The required volume was then carefully discharged onto a weighing boat. A Sartorius MP electronic weighing scale with air cover was used for all the measurements. This was calibrated before use with 100 $\mathrm{mg}$ weights $(n=20)$ and found to be accurate with a standard deviation of $\pm 0.00036 \mathrm{mg}$.

Forty-one repeated measurements were made for each syringe in each of the three bolus sizes. All the measurements of weight were made by a laboratory technician. 
TABLE

\begin{tabular}{llllll}
\hline $\begin{array}{l}\text { Bolus size } \\
m l\end{array}$ & $\begin{array}{l}\text { Syringe size } \\
m l\end{array}$ & $\begin{array}{l}\text { Mean weight } \\
\text { delivered }(G)\end{array}$ & $S D$ & $\begin{array}{l}\text { Range } \\
(G)\end{array}$ & $\begin{array}{l}\text { 95\% confidence } \\
\text { interval for SD }\end{array}$ \\
\hline 1 & $1(n=41)$ & 1.016 & 0.005 & $1.007-1.029$ & 0.004 to 0.006 \\
1 & $3(n=41)$ & 0.978 & 0.020 & $0.948-1.019$ & 0.016 to 0.026 \\
1 & $5(n=41)$ & 0.979 & 0.034 & $0.919-1.058$ & 0.028 to 0.044 \\
1 & $10(n=41)$ & 0.970 & 0.042 & $0.864-1.053$ & 0.034 to 0.054 \\
1 & $20(n=41)$ & 0.974 & 0.054 & $0.840-1.060$ & 0.044 to 0.070 \\
3 & $3(n=41)$ & 2.933 & 0.022 & $2.895-2.969$ & 0.018 to 0.028 \\
3 & $5(n=41)$ & 2.962 & 0.021 & $2.915-3.005$ & 0.017 to 0.027 \\
3 & $10(n=41)$ & 2.939 & 0.043 & $2.826-3.057$ & 0.035 to 0.055 \\
3 & $20(n=41)$ & 2.939 & 0.070 & $2.732-3.057$ & 0.057 to 0.090 \\
5 & $5(n=41)$ & 4.921 & 0.034 & $4.859-4.991$ & 0.028 to 0.044 \\
5 & $10(n=41)$ & 4.900 & 0.070 & $4.736-5.014$ & 0.057 to 0.090 \\
5 & $20(n=41)$ & 4.924 & 0.107 & $4.766-5.211$ & 0.088 to 0.137 \\
\hline
\end{tabular}

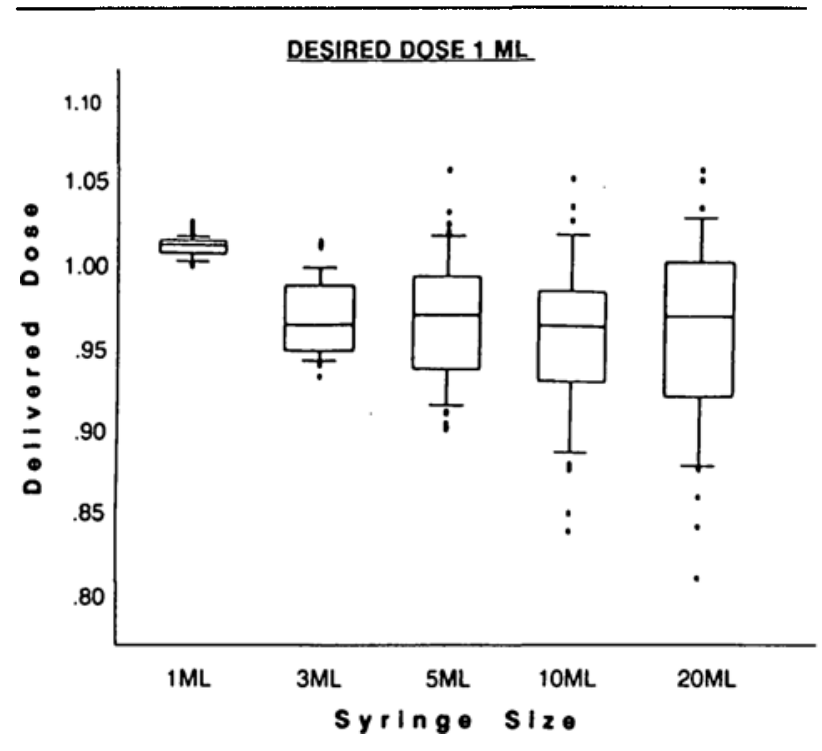

FIGURE 1 Results depicting $1 \mathrm{ml}$ dose, using the box and whisker plot. The shape of this diagram demonstrates the scatter of observations about the median which is represented by the middle of the box. The upper end of the box represents the 75 th percentile and the lower end represents the 25 th percentile of observations. The upper whisker represents the 90th percentile and the lower whisker the 10th percentile, and the dots beyond the whiskers represent the outliers. The accuracy of the syringe is demonstrated by the closeness of the median of the $1 \mathrm{ml}$ syringe to the desired dose of $1 \mathrm{ml}$. The precision of the 1 $\mathrm{ml}$ syringe is demonstrated by the lack scatter of observations about the median. Scatter increased (precision decreased) as syringe size increased.

\section{Statistics}

The volumes delivered are described as mean with standard deviation. The accuracy of each size syringe in delivering a predetermined bolus was compared by performing a one-way analysis of variance test on the means of the volumes delivered. When a statistically significant difference was found Student-Neuman-Keuls test was applied to determine where the differences lay.

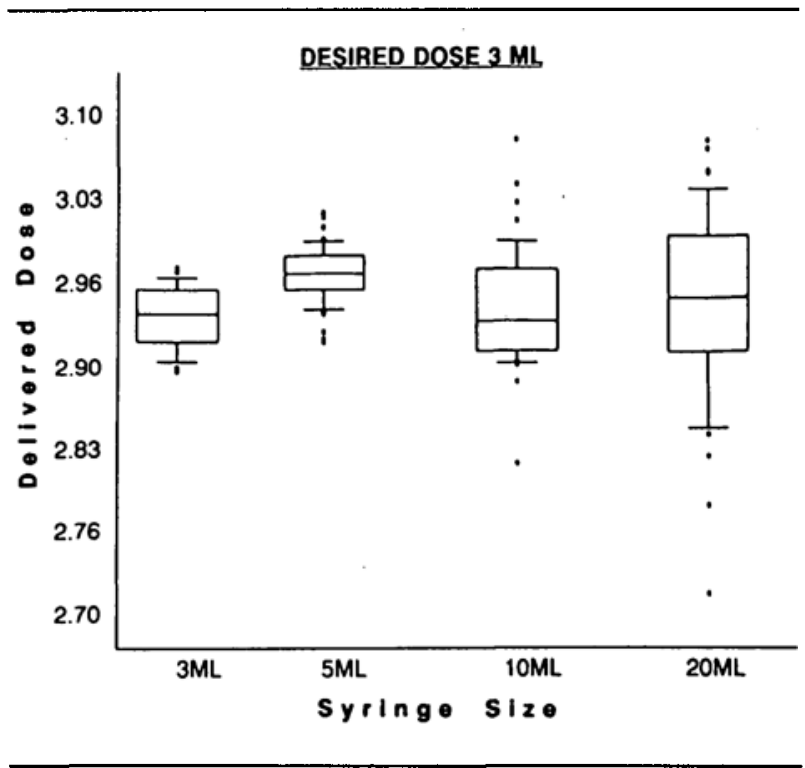

FIGURE 2 Results depicting $3 \mathrm{ml}$ dose. The $5 \mathrm{ml}$ syringe was the most accurate as demonstrated by the closeness of its median to the desired dose of $3 \mathrm{ml}$. The $3 \mathrm{ml}$ and $5 \mathrm{ml}$ syringes were similar in the scatter of observations (precision) about the median. Scatter increased (precision decreased) as syringe size increased.

The variability of the bolus delivered in repeated measurements was tested by applying Bartlett's test comparing variances among different sized syringes for each of the three volumes injected. If the null hypothesis that syringe variances are all equal was rejected, we determined which of the variances differed from which other by applying the Tukey test.'

\section{Results}

The results are listed in the Table and depicted in Figures 1,2 , and 3 . Figure 4 shows the variance in dose delivered by each of the syringes tested.

The Table lists the mean weight, the standard deviation 


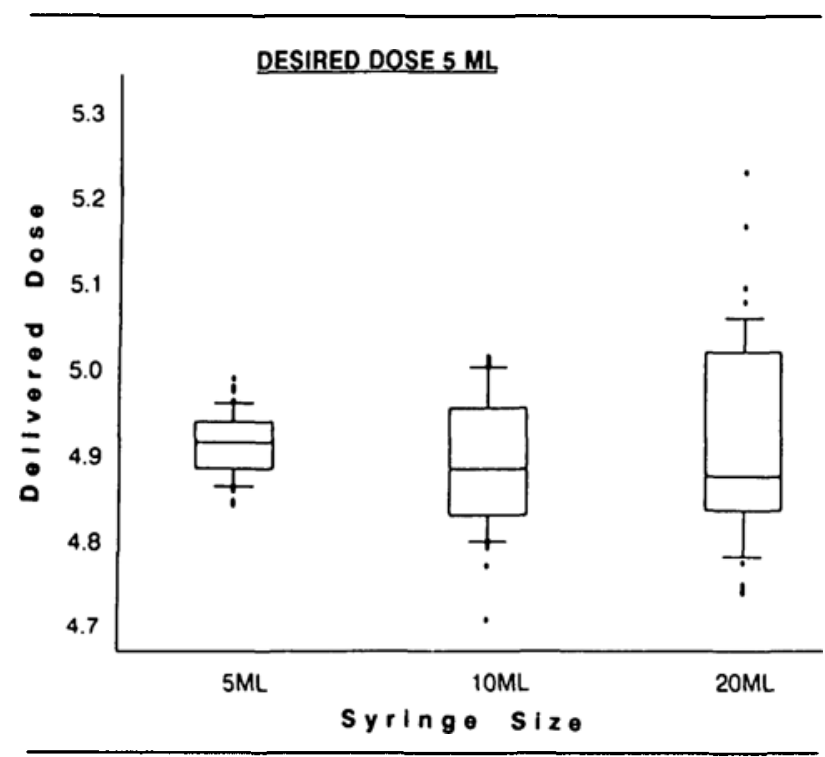

FIGURE 3 Results depicting $5 \mathrm{ml}$ dose. The accuracy of the three syringes tested was similar as demonstrated by the closeness of the medians to the desired dose of $5 \mathrm{ml}$. Scatter of observations about the median increased with increasing syringe size.

(SD), the range of the weights, and the $95 \%$ confidence interval for the $\mathrm{SD},{ }^{2}$ for each volume and each syringe. When delivering a $1 \mathrm{ml}$ bolus, the $1 \mathrm{ml}$ syringe was significantly more accurate $(P<0.001)$ and the bolus less variable $(P<0.001)$ than with any other syringe. The $3 \mathrm{ml}$ syringe demonstrated less variability of bolus weight than the $10 \mathrm{ml}$ or the $20 \mathrm{ml}$ syringe $(P<0.001)$, and the $5 \mathrm{ml}$ syringe showed less variability than the $20 \mathrm{ml}$ syringe $(P<0.05)$. There was no significant difference in the variability of bolus weight between the $10 \mathrm{ml}$ and the 20 ml syringes.

When delivering a $3 \mathrm{ml}$ bolus, the $3 \mathrm{ml}$ and the $5 \mathrm{ml}$ syringes showed less variablity in bolus weight than the $20 \mathrm{ml}$ syringe $(P<0.001)$, the $3 \mathrm{ml}$ syringe showed less variablity than the $10 \mathrm{ml}$ syringe $(P<0.05)$, the $10 \mathrm{ml}$ syringe showed less variability than the $20 \mathrm{ml}$ syringe ( $P$ $<0.05)$. There was no significant difference between the performance of the $3 \mathrm{ml}$ and the $5 \mathrm{ml}$ syringes or between the $5 \mathrm{ml}$ and $10 \mathrm{ml}$ syringes.

When delivering a $5 \mathrm{ml}$ bolus there was no difference in the accuracy or variability of bolus weight between the use of a $5 \mathrm{ml}, 10 \mathrm{ml}$, or $20 \mathrm{ml}$ syringe.

\section{Discussion}

The practice of anaesthesia commonly demands the accurate administration of potent drugs. These drugs are often presented in a concentrated solution and hence the measurement of small volumes is of importance. It has been generally assumed that any volume can most accurately be delivered by using the smallest syringe that

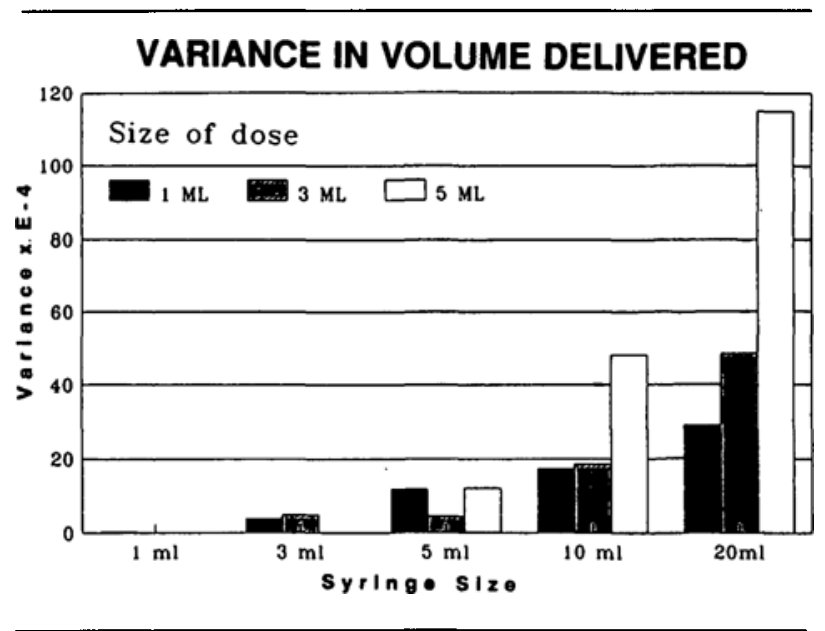

FIGURE 4 Variance in dose delivered by each syringe tested, for each of the three bolus sizes.

will accommodate that particular volume. However, the limits of accuracy when using different-sized syringes to deliver a fixed volume have not been previously documented.

In our studies we used a range of disposable plastic syringes of the type which are most commonly used in general anaesthesia practice. It might be that greater acccuracy could be achieved by using glass syringes but such equipment is not widely used in clinical practice.

We found that the $1 \mathrm{ml}$ syringe was the most accurate and showed the least variability of bolus size when delivering a volume of $1 \mathrm{ml}$. Variability of bolus size increased with increasing syringe size. To deliver a $3 \mathrm{ml}$ bolus the $5 \mathrm{ml}$ syringe was most accurate. Variability in bolus weight again increased with increasing syringe size, being least variable for the $3 \mathrm{ml}$ and the $5 \mathrm{ml}$ syringe. To deliver a $5 \mathrm{ml}$ bolus, although there was more variability in bolus weight with increasing syringe size, when standardized variance was analysed we were unable to demonstrate any significant difference in performance between the $5 \mathrm{ml}, 10 \mathrm{ml}$, or $20 \mathrm{ml}$ syringe. The variability of the 5 $\mathrm{ml}$ bolus size is probably not clinically significant.

Our studies support the thesis that small volumes (1-3 ml) can most accurately be delivered by using a smaller syringe. As the size of syringe increases accuracy declines and variability of dose increases. Therefore we would concur with the advice that small volumes to be administered should be measured using the smallest syringe that will accommodate the desired volume. When volumes of $5 \mathrm{ml}$ were delivered we were unable to demonstrate any difference in performance between $5 \mathrm{ml}, 10 \mathrm{ml}$, or $20 \mathrm{ml}$ syringes.

\section{Acknowledgements}

The authors are grateful to Dr. Lockitch and Jose Briker in 
the Department of Clinical Biochemistry at British Columbia Children's Hospital for their help in the study. We are also indebted to Ms Pamela Merrick for her help in the statistical analysis.

\section{References}

1 Zar JH. Multiple comparisons among variances. In: Biostatistical Analysis. 2nd ed. Englewood Cliffs N.J., Prentice Hall, 1984, 203.

$2 \mathrm{Zar} J H$. Confidence limits for the population variance. In: Biostatistical Analysis. 2nd. ed. Englewood Cliffs N.J., Prentice Hall, 1984, 115. 